\title{
PENGARUH PRA PERLAKUAN SEBELUM PENGERINGAN SINAR MATAHARI DARI KULIT BUAH KAKAO TERHADAP KADAR KOMPONEN FENOLIK DALAM EKSTRAK
}

\section{EFFECT OF PRETREATMENTS BEFORE SUN DRYING ON CACAO PODHUSK AGAINST PHENOLIC CONCENTRATION IN THEIR EXTRACT}

\author{
Sartini ${ }^{1}$, Rangga M.Asri ${ }^{1}$, dan Ismail ${ }^{1}$ \\ ${ }^{1)}$ Fakultas Farmasi Universitas Hasanuddin \\ email :sardj@yahoo.com
}

\begin{abstract}
ABSTRAK
Kulit buah kakao merupakan limbah utama dari pengolahan biji kakao yang kaya akan senyawa golongan fenolik. Senyawa-senyawa ini memiliki implikasi yang menguntungkan bagi kesehatan, tetapi mudah teroksidasi selama proses pengolahan. Tujuan penelitian ini adalah untuk mengetahui pengaruh pra perlakuan sebelum pengeringan di bawah sinar matahari terhadap total fenolik, tannin, dan flavonoid dari ekstrak kulit buah kakao yang dihasilkan. Kulit buah kakao sebelum dikeringkan diberi 3 perlakuan: direndam dalam larutan asam sitrat $1 \%$, larutan metabisulfit 0,5\%, dan tanpa pra perlakuan. Kulit buah kakao tersebut dikeringkan di bawah sinar matahari dengan ditutup kain hitam dan tanpa ditutup kain hitam. Hasil penelitian menunjukkan bahwa ada perbedaan yang signifikan $(p<0.05)$ dari perlakuan yang dilakukan terhadap kadar total polifenol, tannin, dan flavonoid dari ekstrak kulit buah kakao. Pra perlakuan sebelum pengeringan yang direkomendasikan untuk menghasilkan kadar fenolik dan flavonoid yang tinggi adalah kulit buah kakao yang direndam sebelumnya dengan larutan sodium metabisulfit $0,5 \%$ selama 15 menit sebelum dikeringkan di bawah sinar matahari.
\end{abstract}

Kata kunci : pra perlakuan, pengeringan matahari, kadar fenolik, kulit buah kakao

\section{Pendahuluan}

Biji kakao masih merupakan salah satu komoditas ekspor andalan perkebunan yang peranannya cukup penting bagi perekonomian nasional (Pusat Data dan Informasi, 2007). Di dalam pengolahan biji kakao diperoleh hasil samping limbah kulit buah kakao kurang lebih $75 \%$ b/b atau menurut Figuera (1993), pengolahan 1 ton biji kakao kering menghasilkan limbah kulit buah kakao basah sebanyak 10 ton.

Gambaran data ekspor biji kakao tahun 2006 adalah 676.841,385 ton sedangkan ekspor kulit buah kakao kering hanya 1.354,725 ton (Pusat Data dan Informasi, 2007). Ini menunjukkan masih melimpahnya kulit buah kakao yang tidak termanfaatkan. Kebanyakan petani di daerah Sulawesi Selatan hanya menimbun kulit buah kakao di sekitar kebun mereka, sehingga kemungkinan menimbulkan pencemaran lingkungan dan salah satu penyebab penyakit busuk buah pada tanaman kakao. Pemanfaatan dalam bidang peternakan sudah dilakukan tetapi belum dapat mengatasi masalah limbah yang melimpah. Adanya kandungan teobromin yang 
bersifat toksik terhadap hewan dan kandungan tannin menyebabkan penyerapan protein oleh hewan ternak dapat berkurang. Komponen kimia dari kulit buah kakao yang merupakan faktor pembatas bagi pakan ternak (lignin dan polifenol/tannin) ternyata dapat dimanfaatkan sebagai bahan aktif dalam bidang farmasi.

Komponen fenolik kakao, utamanya flavonoid mempunyai potensi sebagai bahan antioksidan alami, antara lain: mempu-nyai kemampuan untuk memodulasi system immun, efek kemopreventif untuk pencegahan penyakit jantung koroner dan kanker (Osawa et al, 2000; Bouchers, 2000; Lamuela-Raventos, 2005; Weisburger, 2001; Lee et al, 2003) dan antibakteri terhadap Streptococcus mutans (Sartini et al, 2009 dan Matsumoto et al, 2004). Hasil ekstraksi oleh Matsumoto et al (2004) diperoleh kadar total polifenol kulit buah kakao yang diekstraksi dengan etanol $30 \%$ adalah $12,6 \%$.

Menurut Sartini et al (2009), kulit buah kakao segar yang diekstraksi dengan aseton $70 \%$ mengandung senyawa polifenol/fenolik yang berpotensi untuk dikembangkan sebagai antioksidan alami dengan $\mathrm{IC}_{50} \quad 0,08 \mathrm{mg} / \mathrm{ml}$ memiliki aktivitas anti Streptococcus mutans. Ekstrak aseton kulit buah kakao juga praktis tidak toksik (Sartini et al, 2008).

Untuk memperoleh bahan baku dalam skala besar tidak memungkinkan untuk mengambil langsung dari petani dalam bentuk segar tanpa mengalami oksidasi dari polifenolnya akibat adanya enzim polifenol oksidase dalam kulit buahnya juga. Untuk itu perlu dicari pra perlakuan dari kulit buah kakao sebelum tahap ekstraksi sehingga tidak menyebabkan menurunnya secara drastis kadar polifenolnya setelah dikeringkan.

Hasil penelitian Sartini et al (2013) diperoleh bahwa enzim polifenol oksidase dari fungi endofit yang diisolasi dari kulit buah kakao dapat dihambat oksidasinya dengan menggunakan zat inhibitor seperti: asam askorbat, sodium-EDTA dan sodium metasulfit.

Dalam penelitian ini telah dilakukan pra perlakuan kulit buah kakao sebelum dan selama pengeringan untuk menentukan cara pengolahan kulit buah kakao sebelum dan selama pengeringan dengan sinar matahari yang dapat diterapkan di tingkat petani, tanpa mengurangi secara signifikan kandungan fenoliknya yang berpotensi digunakan sebagai bahan aktif dalam sediaan-sediaan farmasi.

\section{Bahan dan Metode}

\section{Bahan dan Alat Penelitian}

Buah kakao varietas unggul (Sulawesi I) diperoleh dari Sulawesi Barat, asam gallat (Sigma), katekin (Sigma), asam tannat (Merck), Folin- ciaucalteau (Merck), Aluminium Chloride (Merck), aseton, etanol, air suling, sodium metabisulfit, asam sitrat, dll. Analisis kadar fenolik menggunakan alat spektrofotometer UV-Vis (Agilent ).

\section{Penyiapan Kulit Buah Kakao}

Buah kakao dikeluarkan biji dan pulpanya, kemudian di rendam masingmasing dalam larutan asam sitrat $1 \%$ dan sodium metabisulfit $0,5 \%$ selama 15 menit. Setelah itu buah kakao dikeringkan di bawah sinar matahari dengan dua perlakuan, satu ditutupi dengan kain hitam dan yang satunya langsung dikeringkan di bawah sinar matahari. 


\section{Ekstraksi Komponen Fenolik}

Masing-masing $10 \mathrm{~g}$ serbuk kulit buah kakao derajat halus 30/40, diekstraksi secara maserasi dengan $100 \mathrm{~mL}$ etanol $70 \%$ dan masing-masing digojog dengan menggunakan orbital shaker $120 \mathrm{rpm}$ selama 3 jam. Hasil ekstraksi disaring dan dikeringkan hingga diperoleh ekstrak kental bebas cairan penyari.

\section{Analisis Kandungan Total Fenolik}

Kandungan polyphenol ekstrak ditentukan dengan metode Folin-Ciocalteu. Ekstrak $10 \mathrm{mg}$ dilarutkan dalam metanol, volume dicukupkan hingga $10 \mathrm{ml}$ (1000 bpj ) di dalam labu tentukur. Larutan sampel sebanyak $1 \mathrm{ml}$ ditambahkan $0,1 \mathrm{ml}$ reagen Folin-Ciocalteu (hasil pengenceran 1:1 ml reagen dengan air suling), kemudian ke dalam campuran ditambahkan $0,11 \mathrm{ml}$ larutan natrium karbonat $(75 \mathrm{~g} / \mathrm{l})$ dan volume dicukupkan hingga $10 \mathrm{ml}$ dengan air suling, campuran dibiarkan selama 30 menit pada suhu kamar. Absorban campuran diukur pada panjang glombang 641,5 nm menggunakan spektrofotometer UV-Vis. Kurva standar dibuat menggunakan berbagai konsentrasi asam Gallat (2, 4, 6, 8 dan 10 bpj). Hasil dihitung sebagai persen asam gallat.

\section{Analisis Kandungan Total Tannin}

Kandungan total tannin ekstrak ditentukan dengan metode Folin-Ciocalteu. Ekstrak $10 \mathrm{mg}$ dilarutkan dalam metanol, volume dicukupkan hingga $10 \mathrm{ml}$ (1000 bpj) di dalam labu tentukur. Larutan sampel sebanyak $1 \mathrm{ml}$ ditambahkan $0,1 \mathrm{ml}$ reagen Folin-Ciocalteu (hasil pengenceran 1:1 $\mathrm{ml}$ reagen dengan air suling), kemudian ke dalam campuran ditambahkan $0,11 \mathrm{ml}$ larutan natrium karbonat $(75 \mathrm{~g} / \mathrm{l})$ dan volume dicukupkan hingga $10 \mathrm{ml}$ dengan air suling, campuran dibiarkan selama 30 menit pada suhu kamar. Absorban campuran diukur pada panjang gelombang $765 \mathrm{~nm}$ menggunakan spektrofotometer UV-Vis Kurva standar dibuat menggunakan berbagai konsentrasi asam tannat (2,3, 4, 5 dan 6 bpj). Hasil dinyatakan sebagai persen asam tannat.

\section{Analisis Kandungan Flavonoid Total.}

Kandungan flavonoid ekstrak ditentukan dengan metode Aluminum Chloride colorimetric assay. Larutan ekstrak (10 mg dalam $10 \mathrm{ml}$ ) dan larutan katekin standar $(0,5,10,15,20,25$ dan $30 \mathrm{bpj})$ dilarutkan dalam metanol. Sebanyak $1 \mathrm{ml}$ sampel dipipet dan ditambahkan $0,1 \mathrm{ml} \mathrm{AlCl}_{3} 10 \%$ dan $0,1 \mathrm{ml}$ Natrium asetat $1 \mathrm{M}$. volume akhir dicukupkan dengan air demineralisata hingga $10 \mathrm{ml}$ dalam labu takar. Setelah diinkubasi selama 25 menit pada suhu kamar, absorbansi diukur pada panjang gelombang $281 \mathrm{~nm}$. Konsentrasi dihitung dari persamaan regresi larutan katekin sebagai larutan baku.

\section{Hasil Dan Pembahasan}

Hasil pengukuran komponen fenolik dari ekstrak kulit buah kakao yang diberi kombinasi tiga perlakuan pra pengeringan dan dua perlakuan selama pengeringan berupa perendaman dengan larutan asam sitrat $1 \%$ sodium metabisulfit 0,5\% dan tanpa direndam, dilanjutkan proses pengeringan yang dilakukan di bawah sinar matahari dengan perlakuan ditutup kain hitam dan tanpa ditutup kain hitam, hasilnya dapat dilihat pada gambar 1 dan tabel 1. 


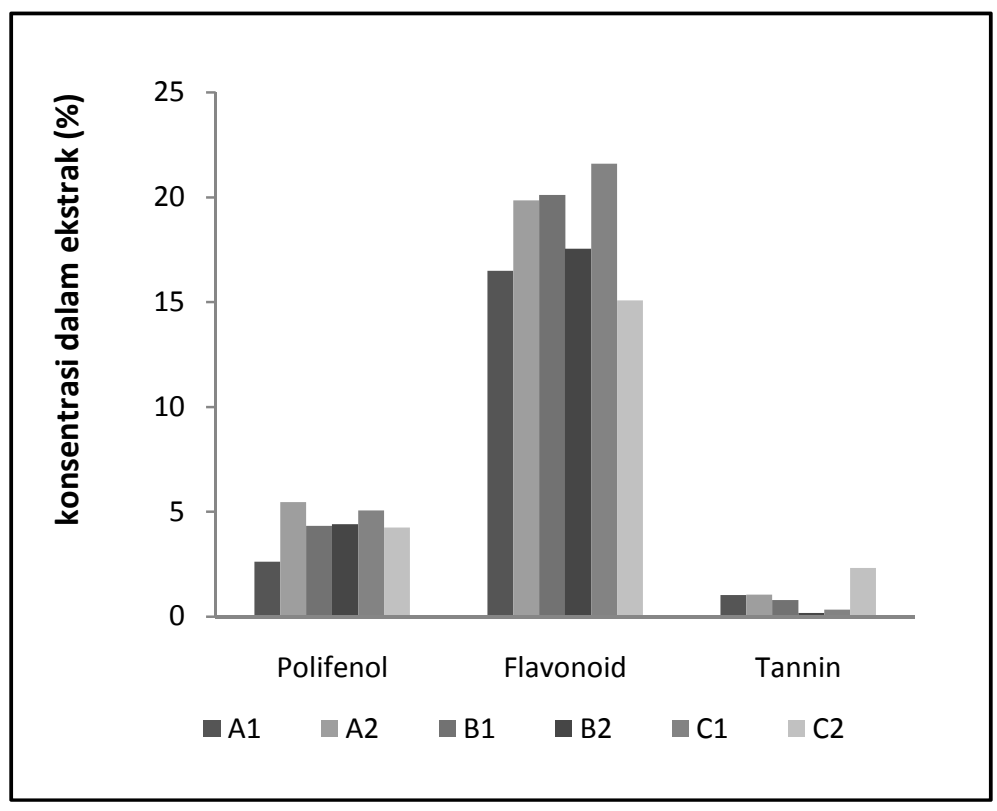

Gambar 1. Pengaruh Cara Pengolahan Terhadap total Fenolik rata-rata (\%) dari Ekstrak Kulit Buah

Tabel 1. Pengaruh Cara Pengolahan Terhadap total Fenolik, Flavonoid, Tannin rata-rata (\%) dari Ekstrak Kulit Buah (replikasi 3 kali)

\begin{tabular}{|c|c|c|c|c|c|c|}
\hline $\begin{array}{c}\text { Kadar Total } \\
(\%)\end{array}$ & \multicolumn{6}{|c|}{ Perlakuan } \\
\cline { 2 - 7 } & A1 & A2 & B1 & B2 & C1 & C2 \\
\hline fenolik & 2,62 & 5,47 & 4,33 & 4,41 & 5,06 & 4,25 \\
\hline Flavonoid & 16,49 & 19,86 & 20,11 & 17,55 & 21,61 & 15,09 \\
\hline Tannin & 1,03 & 1,05 & 0,8 & 0,174 & 0,33 & 2,33 \\
\hline
\end{tabular}

Keterangan :

$\mathrm{A} 1=$ direndam dengan asam sitrat $1 \%$ dan ditutup dengan kain hitam pada saat dikeringkan di bawah sinar matahari

$\mathrm{A} 2$ = direndam dengan asam sitrat $1 \%$ dan tanpa ditutup dengan kain hitam pada saat dikeringkan di bawah sinar matahari

B1 = tanpa perlakuan awal dan ditutup dengan kain hitam pada saat dikeringkan di bawah sinar matahari

B2 = tanpa perlakuan awal dan tanpa ditutup dengan kain hitam pada saat dikeringkan di bawah matahari

$\mathrm{C} 1$ = direndam dengan sodium metabisulfit $0,5 \%$ dan ditutup dengan kain hitam pada saat dikeringkan bawah sinar matahari

$\mathrm{C} 2$ = direndam dengan sodium metabisulfit $0,5 \%$ dan tanpa ditutup dengan kain hitam pada saat di keringkan di bawah sinar matahari

Gambar 1 dan tabel 1 terlihat ada pengaruh pra perlakuan terhadap kandungan total fenolik, flavonoid, dan tannin dari kulit buah kakao. Perendaman dengan asam sitrat $1 \%$ (A2) memberikan hasil kadar total fenolik dan flavonoid lebih tinggi dibanding dengan tanpa perlakuan (B2) dan dan perlakuan dengan sodium metabisulfit $0,5 \%$ (C2), tetapi kadar tannin lebih tinggi pada perlakuan dengan sodium metabisulfit 0,5\%(C2). Perendaman dengan asam sitrat dan sodium metabisulfit juga 
telah digunakan untuk mencegah efek pencoklatan akibat oksidasi dari senyawa fenolik oleh enzim polifenol oksidase yang ada di ubi jalar dan hasilnya perendaman dengan asam sitrat lebih tinggi kadar total feenoliknya dibanding perendaman dengan sodium metabisulfit (Krishnan et al, 2010). Pengaruh perendamam dengan asam sitrat $1 \%$ untuk mencegah oksidase komponen fenolik/flavonoid dengan menghambat kerja enzim polifenol oksidase yang juga terdapat dalam kulit buah kakao (Sartini et al, 2013).

Tambahan perlakuan dengan ditutup kain hitam selama pengeringan di bawah sinar matahari, tujuannya untuk mempercepat proses pengeringan, karena asumsinya kain warna hitam akan menyerap panas sehingga proses pengeringan dapat dipercepat dan oksidasi diperlambat serta kontaminan dikurangi. Hasilnya ternyata kadar fenolik dan flavonoid dari hasil perendaman dengan sodium metabisulfit $1 \%$ (C1) lebih tinggi dibanding dengan perlakuan dengan asam sitrat 0,5\% maupun tanpa diberi perlakuan.

\section{Kesimpulan}

Dari tiga parameter di atas dapat disimpulkan bahwa pra perlakuan sebelum pengeringan yang direkomendasikan adalah kulit buah kakao yang direndam sebelumnya dengan larutan sodium metabisulfit 0,5\% selama 15 menit dan ditutup dengan kain hitam pada saat dikeringkan di bawah sinar matahari.

\section{Daftar Pustaka}

Borchers, A. T. and Keen, C. L. 2000. Cocoa and Chocolate: Composition, Bioavailability, and Health Implication. Journal of Medicinal Food. 3(2): 77-105.

Figueira A., Janick J., BeMiller JN. 1993. New products from Theobroma cacao: Seed pulp and pod gum. In New Crops. Edited by Janick J and Simon J.E. New York: Wiley; 475-478 [online].

Lamuela-Raventos, R. M., Romero-Perez, A. I., Andres-Lacueva, C. and Tornero, A. 2005. Review: Health Effects of Cocoa Flavonoids . Food Science and Tech-nology International . 11(3): 159-176.

Lee, K.W., Kim,Y.J., Lee, H.J., Lee, C.Y. 2003. Cocoa has More Phenolic Phytochemical and Higher Anti-oxidant Capacity than Teas and Red Wine. J.Agric. Food. Chem. 51(25) : 7292- 7295.

Matsumoto M, Tsuji M, Okuda J, Sasaki H, Nakano K, Osawa K, Shimura S, Ooshima T. 2004. Inhibitory effects of cacao bean husk extract on plaque formation in vitro and in vivo. Eur. J. Oral Sci., 112: 249-252.

Osawa, K., Miyazaki , K. , Shimura, I., Okuda,J., Matsumoto, M and Ooshima, T. 2001. Identification of Cariostatic Substances in the Cacao Bean Husk: Their Antiglucosyltransferase and Antibacterial Activities. Dent. Res.80(11):2000-2004

Pusat Data dan Informasi (PDI). 2007. Gambaran sekilas Industri Kakao. Setjen Departemen Perindustrian, Jakarta. 
Sartini, Djide, M.N., Gemini , A. 2008. Effect of cocoa pod husk extracts on prevention of hypercholesterolemia in albino rats (Rattus novergicus). Majalah Farmasi dan Farmakologi. 12(3):78-82.

Sartini, Alam, G., and Djide,M.N. 2009. Eksraksi Komponen Bioaktif dari Limbah Kulit Buah Kakao dan Pengaruhnya terhadap Aktivitas Antioksidan dan Antimikroba. Majalah Obat Tradisional ISSN 14-1410-5918. 14.

Sartini, Patong, A.R., Harlim, T., Pirman. 2013. Production, Partial Purification And Biochemical Characterization Of Polyphenol Oxidase From Tricothe-cium sp (Endophytic Fungus of Cocoa Podhusk). Asian J.of Microbiology Biotechnology and Environ.Sci. 5(4): 621-626.

Sartini, Lidjaja, A., Rivai, Y., and Rahim, A. 2014. Teknologi Pengolahan Limbah Kulit Buah Kakao: Potensinya sebagai Sediaan Komplementer Imunostimulan dan Antivirus bagi Pasien HIV/AIDS. Laporan Penelitian MP3EI. UNHAS, Makassar.

Weisburger, J. H. 2001. Chemopreventive Effects of Cocoa Polyphenols on Chronic Diseases. Experimental Biology and Medicine . 226: 891-897.

Krishnan, J.G., Padmaja, G., Moorthy, S.N., Suja, G. and Sajeev, M.S., 2010. Effect of pre-soaking treatments on the nutritional profile and browning index of sweet potato and yam flours. Innovative food science \& emerging technologies, 11(2), pp.387-393. 